\title{
PIILOSOPMIZZNA
}

IN PLAF(O) GAVE:

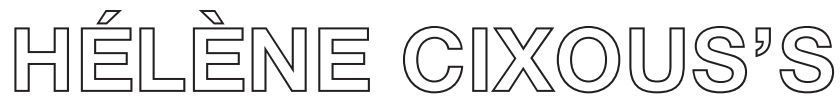

AFFEGIVIE WIRIIING

$\sim \sim$

\section{Eret Talviste}

NORTHUMBRIA UNIVERSITY

\section{ABSTRACT}

Hélène Cixous's work undermines the Cartesian mind-body dichotomy in the Western philosophical canon by (re)writing and (re)constructing history through lived experience and the quotidian. Her writings defy traditional genre boundaries, and I will thus look at both her fiction and non-fiction to suggest that her resistance to genre is a way of creating affective feminist narratives. In combining theory, poetry, philosophy, and personal experience, Cixous creates alternatives to mainstream academic and philosophical writing styles by allowing her writing to be intimately personal, artistic, and creative. I read Cixous's work in the light of contemporary affect theories and new materialism that are influenced by Deleuzian philosophy because the latter are concerned with many of the same issues as Cixousian writing-embodiment, affect, materiality, the non-human, and the move away from dualistic thinking. Cixous's affective writing is an example of philosophy that explores Plato's cave instead of transcending from it into some abstract realm.

\section{KEYWORDS}

Hélène Cixous, feminist philosophy, phenomenology, affect, new materialism 
It is my way of indicating the reserved, secluded, or excluded path or place where you meet those beings I think are worth knowing while we are alive. Those who belong to the birds and their kind (these may include some men), to writings and their kind: they are all to be foundand a fair company it is-outside.

—Hélène Cixous, Three Steps on the Ladder of Writing

Writing follows life like its shadow, extends it, hears it, engraves it.

-Hélène Cixous, Rootprints

Hélène Cixous's writing follows what Gilles Deleuze calls 'a life'-her writing is not engaged with individual linear life narratives of coherent characters but creates a sense of a book which lays everything out on a single sheet: affects, materiality, daily scenes, and philosophical musings. Cixous's work is an assemblage of literary criticism, philosophy, autobiography, and fiction. Her writings defy traditional genre boundaries which encourages me to explore both her fiction and non-fiction to suggest that her resistance to genre is a way of creating affective narratives. I read Cixous's work in the light of contemporary affect theories and new materialisms that are influenced by Gilles Deleuze's and Félix Guattari's philosophy because these theories are concerned with many of the same issues as Cixousian writing, namely affect, embodiment, materiality, the non-human, and the move away from dualistic thinking. ${ }^{1}$ Cixous's work, like much French psychoanalytical thought, Deleuzian philosophy, and theories of affect and new materialism, undermines the Cartesian mind-body dichotomy and Platonic binaries in the Western philosophical canon by (re)writing theory and philosophy through focusing on the quotidian. Cixous's affective writing is an example of writing that is simultaneously poetic and philosophical, thereby exploring Plato's cave instead of transcending from it into an abstract realm. ${ }^{2}$

In what follows, I will discuss Cixous's theoretical writings such as "Sorties" (1975), “The Laugh of Medusa” (1975), Three Steps on the Ladder of Writing (1993), and Rootprints (1994), to demonstrate how her concept of écriture féminine has developed over decades and should be examined alongside contemporary studies in affect and new materialism as well as being read in French psycholinguistic tradition. I read closely Cixous's novel Hyperdream (2006) to explore how she depicts what Deleuze defines as 'a life' in "Immanence: A Life" (1995). I begin by examining the idea of a self as an assemblage of a life in Hyperdream, and how Cixous expresses this idea in writing. I then look at embodied, non-human 
affects to finally explore the "texxture" of material things, whether human or non-human, and return to the importance of embodiment and touch (physical or otherwise) in affect and affective writing. I propose that in Cixousian writing a self becomes an affective assemblage in relation to and with other bodies, and that for this reason, the self in Cixous's fiction cannot be understood merely in terms of psychoanalytical and deconstructionist models, but has to be examined with theories of affect and new materialism.

\section{A life, and a self as an assemblage in Hyperdream}

Hyperdream does not deal with identity, autobiography, or characters in the traditional sense; it is not a feminist confessional narrative but a meditation on affective experience of the narrator's own singular subjectivity which is an assemblage of memories, hopes, dreams, daily life, and materiality of things and other people. The narrator takes an everyday scene, usually a scene from a daily life-her mother laughing, the narrator sitting among her books or staring at an old bed, or losing her nightdress. Hyperdream is a novel par excellence of haecceities (not just her mother but her mother's moods and appetites in specific times of a day or a year; not the whole bed but mattresses and corkscrews and frames and their relation to the narrator and their changing meaning in time), of hopes, dreams, memories, losses, mourning, mornings, and cats. ${ }^{3}$ It is written as a first-person narration and although the reader never learns who this ' $I$ ' is, we can assume by references to a friend called 'JD' to be Jacques Derrida, and a certain mother Eve, and to past history of growing up in Algeria as a Jewish French girl, that the narrator is a version of Hélène Cixous. Mairéad Hanrahan proposes in "Of Altobiography" (2000), that like many of Cixous's novels, Hyperdream is altobiography-not autobiography but biography of alterity(ies) of oneself.

However, it seems there is no one self in Hyperdream, as the novel explores the thoughts around Walter Benjamin's bed, the narrator's nightdress, and her mother's skin, to show how materiality and the different ways it affects us makes us different subjects in each specific relation. The characters (if one can call them so) in Hyperdream do not have linear and coherent subjectivity but a subjectivity that is fragmented. That is, none of the characters in Hyperdream have a full name: only JD is used, and the narrator's mother is sometimes called Eve. Otherwise, only words like 'brother', 'mother', 'friend', and 'beloved' are used. Neither does the narrator ask who the self is who speaks, and what it means to be this self, but asks something small, like "what is my mother doing" and "what can this bedframe tell me", and from those questions, via poetic musings, she begins to explore philosophical questions about life and selfhood. 
All these questions and their potential answers are given equal importance and space for contemplation in Hyperdream. In A Thousand Plateaus Deleuze and Guattari write: "The ideal for a book would be to lay everything out ... on a single page, the same sheet: lived events, historical determinations, concepts, individuals, groups, social formations. Kleist invented a writing of this type, a broken chain of affects and variable speeds, with accelerations and transformations, always in a relation with the outside" $(1980,10)$. Cixous too is theorising this kind of writing, as well as practising it in her fiction. Hyperdream feels like a text that could and should be laid out on only one sheet, where all events, both virtual and actual, happen at the same time, where all objects and people are equally relevant at all points in time, and where inside and outside (material and psychological) are depicted equally. Perhaps the most apparent stylistic device to create the effect of a single page is the use of repetition. In Hyperdream paragraphs and phrases are recycled and repeated and reimagined. For instance, phrases like "you can always lose more" (Cixous 2006, viii, 10), "I mean the ultimate, the last last" (Cixous 2006, vii), "the ultimates-the last lasts-I'm in them" (Cixous 2006, viii, 6), are repeated from the beginning of the text, though slightly altered each time, to demonstrate how thought grows and changes around these phrases-how the same phrases lead to different virtualities, depending on the moment and situation the narrator is in when the thought comes to her. Towards the end, the narrator also acknowledges that: "my book I say is on the move, we are moving each other" (Cixous 2006, 78). In Hyperdream, writing is not something the author/narrator does, but something that also does the author/narrator. Deleuze and Guattari write in $A$ Thousand Plateaus: "contrary to the deeply rooted belief, the book is not an image of the world. It forms a rhizome with the world, there is a parallel evolution of the book and the world" $(1980,12)$.

The same is happening in Hyperdream-as a novel, a physical book, Hyperdream is not beyond or outside a life but embedded within it. In "Immanence: A Life", Deleuze describe 'a life' that is not subjective but is impersonal and asubjective; an assemblage of all things, animate and inanimate, natural and artificial. He writes, "we will say of pure immanence that it is A LIFE, and nothing else. A life is everywhere ... an immanent life carrying with it the events and singularities that are merely actualized in subjects and objects" (1995, 27-29). A life is not something that happens to an individual or something that individual does or has; a life is immanent in itself. Something very similar to a life seems to be depicted in $\mathrm{Hy}$ perdream-a life of a singular version of Hélène Cixous lived in relation to other singularities, existing in objects, expressed in a book that is written by her while the book simultaneously also writes her into the book. 
The idea of a coherent self is overthrown in a life. Deleuze argues in "Immanence: A Life" that "the real problem dramatized in Hume's humorous picture of the self as incorrigible illusion is how our lives ever acquire the consistency of an enduring self, given that it is born of 'delirium, chance, indifference"' $(1995,26)$. Deleuze then explains, referring to a dying character in Charles Dickens' novel:

Between his life and his death, there is a moment that is only that of a life playing with death. The life of the individual gives way to an impersonal and yet singular life ... The life of such individuality fades away in favor of the singular life immanent to a man who no longer has a name, though he can be mistaken for no other....This indefinite life does not itself have moments, close as they may be one to another, but only between-times, between-moments; it doesn't just come about or come after but offers the immensity of an empty time where one sees the event yet to come and already happened, in the absolute of an immediate consciousness (1995, 27-28).

The nameless yet singular and recognisable characters, also seemingly existing between life and death in Hyperdream, all seem to inhabit this in-between time, freed from their subjective lives, yet very present in their singular life. From the beginning, the narrator muses:

The ultimates-the last lasts-I'm in them, I know this now without knowing it except in every pore of my being. These times are divided into two stretches of time, shifting, unstable, like two transparent continents that in turn meet mingle, mix, separate. There's the time before the interruption of my mother. There's the time after the interruption of my friend. Henceforth I am paradoxical. I am before after and after I am late and I am early (Cixous 2006, viii).

She explains how the ultimate last times do not have a date; that she knows this not as a human subject orienting in human time but knows this because she feels it in her pores. I will return to the importance of embodiment in relation to this knowledge shortly. For now, it is important to stress that although there are specific dates in the novel, the general timeframe or feeling of time in the novel is that of in-betweeness that the narrator describes in the above quotation. Importantly, the interruption here stands for death, meaning that like Deleuze's reference to Dickens' dying character, the in-betweeness of Hyperdream is also an in-betweeness of life and death. In this in-betweeness, time is suspended, and so is subjectivity-a self becomes an assemblage with that which is outside of itself and lets itself be made and remade by this in-betweeness in time and of encounters with other nameless singularities.

\section{Écriture féminine as affective writing}

But how, then, to write a book that is capable of depicting asubjective yet singular life? Cixous's contemplates that question throughout her oeuvre and explores such writing in her concept écriture féminine. She first introduces écriture féminine in her 
1975 essays "Sorties" and "The Laugh of Medusa". In both essays, she sees writing "the feminine", writing the body, and writing the other as possible alternatives to Western philosophical canon (Plato, Aristotle, Descartes, Hegel) and critical writing and thinking that stems from the aforementioned philosophers' works and produces phallocentric, xenophobic, and misogynist narratives. Cixous's writing is informed by that which is considered feminine in the Western philosophical thought; écriture féminine engages with the qualities that are on the right of the binary oppositions outlined in "Sorties": Head/Heart, Intelligible/Palpable, Logos/Pathos, Mind/Body. Cixous's oeuvre in its entirety is dedicated to deconstructing these dualistic binaries; a dedication which is entrenched in French psychoanalytical and deconstructionist thought, notably articulated by Jacques Derrida, whose work has a central importance to Cixous, and also in the French feminist tradition-Luce Irigaray, Julia Kristeva, Monique Wittig, and Cixous herself. The latter tradition, for instance, pays attention to that which is feminine largely because Freudian psychoanalytical thought and Western philosophy fail to include the feminine in theorising and philosophising. ${ }^{4}$ In Rootprints, written in the early 1990s, Cixous explains how her work in the 1970s served a political purpose-it drew attention to the underrepresentation of women in the public sphere and the psychological and historical reasons around it (Cixous 1994, 20). Accordingly, much criticism on Cixous's work has centred around its political impact. ${ }^{5}$ Instead, I draw on the aspects of écriture féminine that are less explicitly concerned with gender roles in a social and political context-I focus instead on materiality and affectivity, and how the radical alterity that femininity marks also expands to the world of non-human. Because of the way that Cixous's concept of écriture féminine has developed over decades, it is important to acknowledge the centrality that affect and materiality play in her writing. This shift in focus demonstrates how the so called 'feminine qualities' are rather affective, and how including them helps to develop a writing that is also affective, and that has the potential to write asubjective yet singular narratives.

Such writing, however, requires thinking through ways that are not yet thought in most traditional philosophical discourses. That is, if traditional philosophical discourse is thought to be rational, then écriture féminine also leaves space for that which is affective and emotional. Elizabeth Grosz explains that the modern style for philosophical discourse is based on its separation from poetry and myth (1990, 150). She notes that Homer's The Iliad and The Odyssey embody philosophical, psychological, poetic, theological, and narrational features, and proposes that 
it was around the fifth and the third centuries BC that philosophical discourse gained specific standards and style (Grosz 1990, 147-175). It was then when "its propositions gain precise, unambiguous formulation and a truth-function; only, that is, when philosophy carefully controls language, clears up 'poetic' ambiguities, is cast into a propositional form, placed within the structure of the logical syllogism and assessed in terms of truth and validity will a statement become philosophical" (Grosz 1990, 147). Grosz argues that the project of feminist philosophy is, with its focus on poetics, rhythm, and sensory experience, a revolt against the traditional philosophical discursive style. ${ }^{6}$ Grosz does not give specific examples from philosophical writing that works with poetics, but it is in Deleuze and Guttari that we find references to various philosophical novelists such as Kafka, Woolf, and Kleist. In What is Philosophy? Deleuze and Guttari say that, although they acknowledge that art deals with affects and percepts and philosophy with concepts, "art thinks no less than philosophy," and that they "often pass into each other in a becoming that sweeps them both up in an intensity which co-determines them" (1991, 65-66). Such an approach allows seeing Cixous's fiction writing as philosophy that includes poetry, myth, and the everyday in philosophical musings.

Cixous seeks a new mode of writing in écriture féminine that could write the myriad, affective ways by which selfhood and subjectivity is constituted in a life. That kind of writing for her is:

the passageway, the entrance, the exit, the dwelling place of the other in me-the other that I am and am not, that I don't know how to be, but that I feel passing, that makes me live-that tears me apart, disturbs me, changes me, who? - a feminine one, a masculine one, some?-several, some unknown, which is indeed what gives me the desire to know and from which all life soars (Cixous 1975, 201).

Here, the emphasis is not so much on self and other anymore, but on various multiplicities: "a feminine one, a masculine one, some?-several, some unknown" (Cixous 1975, 201). The feminine here is no longer a biological difference of the female body, but a signification of radical alterity, or rather, multiple alterities. I briefly want to turn to Deleuze's and Guattari's 'multiplicity' here, as their term might help to clarify Cixous's criticism of Western philosophy and especially Plato. Nicolas Tampio explains in Encyclopedia of Political Theory that "Deleuze employs the term multiplicity as part of his broader project to overturn Platonism" (2010, 911). Tampio writes that:

Platonism codifies the commonsense belief that human concepts match up with nature's articulations. Plato posited a universe of the One and the Multiple in which humans perceive inferior copies of perfect ideas ... for 
Deleuze, the task of modern philosophy is to break from the Platonic cast of mind and grasp multiplicities in their singularity. A multiplicity is neither a copy of a model nor a fragment of a higher totality, but a purely unique event (2010, 911).

Deleuze, like Luce Irigaray in Speculum (1985), criticises as false Plato's idea of a dichotomy between copies and originals. In the same way, Cixous also engages with multiplicities not binaries. Her engagement with multiplicities helps her to invent and practice the kind of writing that is both conceptual and affective. In this writing, what matters is not individual subjects with their life histories, but virtual and actual assemblages these subjects form with the world around them, creating a singular life.

Although affects are thought to be non-subjective, in Cixousian writing, experiencing them starts from an embodied subject, even if this subject is fractured. In fact, the fractured subjectivity, the acknowledgment of one's self as an assemblage might be what makes one open to experiencing affect. In the quotation from "Sorties" cited above, the awareness of a multiplicity comes from the sense of being embodied: "the other that I am and am not, that I don't know how to be, but that I feel passing, that makes me live-that tears me apart, disturbs me, changes me.... what gives me the desire to know and from which all life soars (Cixous 1975 201, emphasis mine). For Cixous, life, the desire to live, and being alive are triggered by sensations of the body that acknowledges its multiple nature. Embodiment is also emphasised in the quotation from Hyperdream where the narrator muses that she is in "the ultimate last last times," knowing it "without knowing it except in every pore of [her] being" (Cixous 2006, viii, emphasis mine). The pores of her being are bodily-she knows this not by mind but by body, sensations, and each pore of her bodily experiences. The emphasis on bodies is already present in Cixous's early writing. In "The Laugh," she emphasises the importance of the intelligence of the body, arguing that if you "censor the body you censor breath and speech at the same time" (Cixous 1975, 880). She argues that when she writes: "I, too, overflow; my desires have invented new desires, my body knows unheard-of songs" (Cixous 1975, 876). Cixous suggests that writing like this "[takes] place in areas other than those subordinated to philosophico-theoretical domination" (Cixous 1975, 883). That is, it takes place in the body or via the body. In What is Philosophy? Deleuze and Guttari write that "aesthetic composition is the work of sensation" (1991, 291). For them, good art, including good novels depict percepts and affects: "percepts are no longer perceptions; they are independent of a state of those who experience them. Affects are no longer feelings or affections; they go beyond the strength of 
those who undergo them" (Deleuze and Guattari 1991, 164). Yet, for Cixous, affects, and writing affectively, do begin in an embodied subject, even if this being who is embodied changes in time and forms various new assemblages with other bodies constantly.

\section{Writing embodied affects and non-human assemblages}

In Rootprints, an interview-format book, Cixous talks about affect, contemplating that human behaviour and feelings are influenced by "the flood of affect that manifest themselves in our body and influence our being" (Calle-Cruber and Cixous 1994, 18). Thinking about the nature of affect, sensation, and experience, she muses that: "It begins in this way, and it is only belatedly, and to go quickly, to sum up, that we give general and global names to a whole quantity of particular phenomena" (Calle-Cruber and Cixous 1994, 18). That which begins this way refers to the experience that starts in our body, through our senses; a feeling that we cannot name until time has passed and words and concepts invented for what we felt. In other words, it is affect that a body experiences and from which writing starts for Cixous. For her, writing begins in the same place as affect, with the same sensation in the body; it comes, as she states in Three Steps on the Ladder of Writing, "from the heart where passions rise to the finger tips that hear the body thinking: this is where the book springs from" (Cixous 1993, 156). Yet, Cixous is not reducing the self and affects the self experiences merely to a single body. Rather, she is saying that what is often ignored is perhaps that we are realized by our bodies. That is, we are something beyond our bodies: we lose parts and shed cells, also regenerate, but remain ourselves in relation to things and people that surround us - for example, our mothers, our nightdresses, and our furniture. What remains are the assemblages that were formed in the process of the meeting of various bodies, human and non-human. In fact, like Deleuze, Cixous does not really want to call a body 'a body' because she means various small complex parts of various matter (cells, nerves, tissues) that make up the body. By including the fleshy, mattery part of bodies in her writing, Cixous challenges the dominant discourses and genre boundaries, letting her affects overflow.

Although Cixous is careful of not falling into the idea of a coherent self, or of clarifying purely human subjectivity, humans and humanity are still relevant for her theorising. In Rootprints, Cixous indicates that:

the word human is very important. When I say 'more human,' I mean: progressing. I ought to say: better human. This means, while being human, not depriving oneself of the rest of the universe....After all, what do we do? We live, but why do we live? I think: to become more human: more capable of 
reading the world, more capable of playing it in all ways. This does not mean nicer or more humanistic. I would say: more faithful to what we are made from and to what we can create (Calle-Cruber and Cixous 1994, 30).

But what are we made from and what can we create? Cixous has a potential answer, suggesting that humans are made of the rest of the universe, which perhaps indicates that humans are not separated from the rest of the world of animate and inanimate matter, or that humans are more-than-human (cells, nerves, tissues). Materiality for her, or what she calls the rest of the universe, is there to remind us that human subjects are not abstract but embodied in the world among other beings and things, and that is what makes them perceptible as affecting and being affected, as well as writing affectively. Perhaps it can also be said that for Cixous, affect is never purely human or non-human, it is the encounter between the two, and the acknowledgement of that encounter.

Accordingly, even if affect begins in a specific embodied subject, it does not remain subjective, or become subjective. In What is Philosophy? Deleuze and Guattari write: “affect is not the passage from one lived state to another but man's nonhuman becoming... It is a zone of indetermination, of indiscernibility, as if things, beasts, and persons. Life alone creates such zones where living beings whirl around, and only art can reach and penetrate them in its enterprise of co-creation" $(1991,173)$. In other words, art can capture a human's non-humanity, or humanity that is itself partly non-human and material. In Three Steps, Cixous creates an image of the ladder of writing that descends towards the ground rather than ascending-an image that I would also like to see as a critique of philosophy's Platonic desire to ascend from the cave rather than exploring the cave. It is a final step in the ladder of writing leading towards affective writing that is not afraid to capture the asubjective, more-than-human part in humans.

In the "School of Roots" section which is the last step on the ladder of writing in Three Steps, Cixous focuses on materiality, embodiment, and on that which lies on the ground, and also on that which lies deep inside the human psyche. Her ladder of writing does not reach for the sky but remains on the ground and goes deep into the earth, where humans meet animals, vegetables, and other non-human animate and inanimate matter. Cixous writes:

It is my way of indicating the reserved, secluded, or excluded path or place where you meet those beings I think are worth knowing while we are alive. Those who belong to the birds and their kind (these may include some men), 
to writings and their kind: they are all to be found-and a fair company it is-outside; in a place that is called by Those Bible, those who are the Bible, abominable... Outside we shall find all those precious people who have not worried about respecting the law that separates what is and is not abominable according to ThoseBible (Cixous 1993, 883).

Cixous names writers like Jean Genet and Clarice Lispector, and says their writing inhabits the nether realms which are closer to the physical world where different beings reside. Referring specifically to Lispector's work, Cixous explains that conventions ask people to repress in writing that which they are made of, matter, because matter, according to the Law, is abominable. Interestingly, the Latin roots of 'abominable' refer to "away from man," and to "beastly," according to the Oxford English Dictionary, establishing a concrete relation between matter's non-humanity, even beastliness, and the dislike of it.

To challenge this perception, Cixous follows Lispector to argue that matter is far from being dislikeable, but is intelligent, alive, and powerful:

[Clarice Lispector] returns the ability not to forget matter, which we don't notice: which we live, which we are. Clarice descends the ladder to the point of returning to think over matter. We are unable to think matter because we consider it to be invisible. We are made of assemblings that hide their truth, their atomic side, from us. We dislike matter, that is, ourselves, because we are destined to matter, because anonymous matter is called: death. Perhaps it isn't matter we dislike, perhaps it is anonymity (Cixous 1993, 130).

The above quotation demonstrates the importance of matter in Cixous's work by drawing attention to the fact that we often forget matter because it is an encompassing part of our existence, something that we take for granted. The books that include matter are for Cixous rebellious books, "book[s] without an author... book $[\mathrm{s}]$ that take life and language by the roots... [books that are written] from the heart where passions rise to the finger tips that hear the body thinking" (Cixous 1993, 156). Cixous does not fear the anonymity of matter. On the contrary, she embraces it because for her our physical bodies remind us that humans are a part of the rest of the universe of molecules, cells, and other non-human phenomena. Instead of pursuing the transcendental by reaching for light and escaping the cave as much of Western philosophy does, Cixous encourages us to stay in the cave, to wonder about our bodies, and understand our lives in relation to the non-human world of animate and inanimate matter that we inhabit side by side with plants, animals, and microbes.

If Cixous theorises about matter in Three Steps, then in Hyperdream she explicitly includes matter in her writing. There are concrete material objects that affect the narrator-these objects do not represent careless capitalist consumerism, but intimate relation to everyday practical things such as pots, mirrors, pens, beds 
and other familiar objects-without which, the narrator writes, "the dead would be lost, terrified by death, tormented by the prospect of the voyage to the foreign land" (Cixous 2006, 72). Contrary to the idea that matter is anonymous and close to death, the reverse happens here-life depends on matter. The narrator talks about a bed, which her mother had supposedly purchased forty years ago from a certain Mr. Walter Benjamin. Until her mother tells her that she bought the bed from that Benjamin, the bed was regarded as a simple everyday commodity. After her mother tells her, however, the bed obtains a special status for the narrator. She muses: "I feel myself loving [the bed] for each of the powers fate has endowed it with: history, philosophy, neurosis, friendship, chagrin, the ideas of immortality, the genius of dreaming, the mystery of the resurrection, the resistance to being reduced to nothing" (Cixous 2006, 73). The narrator knows that the bed only has meaning through her. She wonders: "its esthetic value, this depends on me. On my gaze. On the way my skin, my surface, my depths receive the traces of twentieth-century history as it was lived and recorded by this bizarre machine with its cork-screw vocal cords. For the bed speaks. But it only speaks if you speak to it" (Cixous 2006, 74). The bed is wide open to the narrator-it offers her insights into the twentieth century's history and philosophy-this physical object of non-human matter is what makes the narrator wonder about not just her personal life but a life - and makes her write down this life.

When the above passage focuses on the human mind and how subjectivity shapes our understanding of object world, then there are instances in Hyperdream when objects gain more explicit vitality. For example:

[The bed] lay there. I imagine it suffering, if it has a soul, as being similar to that of an old mother-in-law who keeps herself busy in the kitchen enveloped in a silence beneath which she shuts up a terrified prayer: may I not be sent to the hospice. As part of the bed the least visible furthest removed from the fabrics and the body you might say the bedframe occupied the lowest, humblest place,...What's a bedframe? It is as yet unthought. Wretched I am for everything that has not yet been thought and only my friend could have thought...Who will swear [the bedframe] hasn't a soul? Who will say what quantity of soul is containable and contained in its frame, its corners, its springs, its empty space? (Cixous 2006, 73).

She muses that the bed has a specific "force", a "secret strength" that lodges in the metal of the bedframe, which she associates with old age, and wisdom, but also with the "lowest, humblest place" because it is mere material object (Cixous 2006, 73). Here, like in "The School of Roots," the narrator asks us to think about that 
which is not yet thought-matter. Because materiality is no longer equivalent to anonymity and death but becomes that from which the desire to think, know, and live springs. In fact, it is through matter that the mother in law's prayer not to be sent to hospice might be answered-the very human desire to live, and to be remembered, can happen through objects.

It is clear from the above passage that as far as the human subjectivity perceiving the object is concerned, senses are relevant. The object's ability to affect us depends on the tactile, whether this tactile is via physical touch or simply gazing, as was the case with the bed. When it comes to the narrator's mother and her nightdress however, physical touch, and the relevance of skin becomes apparent. For example, thinking of the nightdress that the narrator loses, she laments:

This gown I said for me evokes Venice, Prague, Rome, Edinburgh, Cambridge, Bombay, the desire to go there, the anguished happiness of having been there, the fear of returning and of not returning, and it is not merely the nightdress, it's the whole Hotel, and dozens of moments followed by poems, I said, I cried, I went crazy. And the disaster?... It was as if they'd stolen my skin (Cixous 2006, 70).

The nightdress here stands for an inhuman, or more-than-human part of the narrator-her skin. The nightdress, that is her skin, is not just a nightdress or a skin but something similar to a Deleuzian assemblage; it is a network of all the cities the narrator has visited and all the memories made and feelings experienced there. The stealing of her skin-like nightdress is not tragic because of its commercial value, but because it holds parts of the narrator's self.

\section{Affective texxture}

The metaphor of the skin is also important because of its tactile properties. The nightdress, and her mother's skin, to which I will turn to shortly, are relevant as they embody stories that can be touched. Similarly, the text in Hyperdream, or Hyperdream as a book, functions as an object that touches the reader; both its 'texture' and 'texxture' are significant. Sarah Jackson in "So Close: Writing that Touches” (2012), refers to Renu Bora's, and Eve Kosofsky Sedgwick's reading of Bora, arguing that texts have both 'textural' and 'texxtural' qualities. What Bora calls 'texture,' "signifies the surface resonance or quality of an object or material. That is, its qualities if touched, brushed, stroked, or mapped, would yield certain properties and sensations that can usually be anticipated by looking" (Jackson 2012, 414). 'Texxture,' on the other hand, "refers not really to surface or even depth so much as to an intimately violent, pragmatic, medium, inner level (at first more phenomenological than conceptual/ metaphysical) of the stuffness of 
material structure" (Jackson 2012, 414). For Sedgwick, texture blocks or defies object's history, but "texxture is the kind of texture that is dense with offered information about how, substantively, historically, materially, it came into being" (Jackson 2012, 414). The ability to affect depends precisely on the thing's texxture. Benjamin's bed and the narrator's lost nightdress, and the narrator's mother's skin in Hyperdream play with the importance of objects' texxture. For example, in the above passages about the bed, the narrator touches the bed with her gaze, and in exchange the bed touches her with stories of the past, and her nightdress has almost become her skin. Texxturality of these objects allows the reader to learn not only about the narrator's life though the past of those objects, but to see life as a life, as a web of connections. The text itself too becomes intense with meaning through objects' texxture and thus encourages the reader to be touched by its texxture, just like the physical touch between the narrator and her mother is conveyed from the story to the reader.

Some of the most important everyday moments in Hyperdream are the moments when the narrator has to anoint blisters on her mother's ill and aged (dated) skin. At first, anointing is annoying, even repulsive for the narrator, but gradually she starts to see these moments of anointing as special. The touch of her mother's skin is presented as the main form of communication in the novel between the narrator and her mother. That is, affect transfers from the narrator's mother's skin - from matter and its texxture - to the narrator through sensory knowledge and physical touching; the narrator is feeling her mother when she anoints her mother's skin, and through her skin, gains knowledge of time and history, just as she did with the bed.

In "Sorties", Cixous writes that "History [is a] history of phallocentrism, history of appropriation: a single history. History of an identity: that of man's becoming recognised by the other (son or woman)" (Cixous 1975, 204). In Hyperdream, history gains new meaning-it is no longer a single history, but an assemblage of multiple stories, accessed by the narrator via an encounter with the texxture of the people and objects she meets, and touches. During the moments when the narrator anoints her mother's skin, she tells her mother: "you are time," while continuing to think: "the far-off bottom of my whole history" is "what is right under my eyes, beneath my nose, my mother's skin" (Cixous 2006, ix). Here, the narrator discredits the binary where a woman is equated with space and body rather than time and mind. The narrator's mother's skin is more accurate canvas for learning 
about the past than books, databases, and archives, as her skin has experienced what might be called life or history. The narrator refers to "time's horizon-line" that also opposes the hierarchical, vertical way of writing and thinking about history where the political and the public are more important than the personal, the intimate, and the poetic:

It crosses my mind that the skin of my mother standing in front of me this July morning in which we go on living, in which, that is, life continues to weave its fabrics within the framework of the body of my mother and within the framework of my body-that my mother's skin, dated, would be the most faithful canvas, or mirror or painting of my most basic, dated state of mind and soul, or of what one calls life, or maybe time's horizon-line on which are painted or deposited the physical effects of what we happen to live (Cixous 2006, ix).

In other words, seeing the horizon line allows seeing the past as a whole, including women and the quotidian, private experiences. There is beauty and knowledge that comes from touching her mother's wounded and wrinkled skin because she sees a life, not just her and her mother's lives, but all kinds of stories, by touching her mother. Through her skin the narrator learns about German, French, Algerian, and Jewish history.

When Cixous uses the word 'history' in Hyperdream, she uses it to denote its phallocentric nature. Her mother's skin is time, and a different kind of history for her, as she muses: "I could no longer stop thinking about time, about time and times. [while I] cultivate time with both hands, one on top of the other hers yours mine ours, I spread them, I browse and I ruminate the future" (Cixous 2006, vii, x). As suggested at the beginning of this essay via Deleuze, the time in Hyperdream is in-between times, suspended. Instead of creating a historical linear timeline, the narrator creates something very similar to Deleuzian sense of a life in in-between time. And this life, like an ideal book in Deleuze's and Guattari's sense, is laid out not on a single sheet, but on a skin of one person, or in a bed, or a nightdress in Hyperdream, or indeed the physical book itself. Importantly, it the affective texxture of these things that allows the narrator to sense how her self, and her life is an affective assemblage with these things.

Texxturality of objects and things is important precisely because it draws attention to the affective encounter that happens between humans and the non-human. Melissa Gregg and Gregory J. Seigworth suggest in The Affect Theory Reader that:

affect arises in the midst of inbetweenness: in the capacities to act and be acted upon... affect is found in those intensities that pass body to body (human, nonhuman, part-body, and otherwise), in those resonances that circulate about, between, and sometimes stick to bodies and worlds, and in the very passage or variations between these intensities and resonances themselves $(2010,6)$. 
This in-betweenness exists both between human self and human other, and also in the in-betweenness of human self and non-human other in Hyperdream. Russell Pavlov-West in Temporalities highlights Bruno Latour's suggestion that the conception of a multiplicity of human, animal, plant or mineral actors "blurs the organic and inorganic by emphasising an order of ceaseless connection and reconnection" (Pavlov-West 2013, 154). Latour suggests that "if the opposite of being a body is dead [and] there is no life apart from the body ... [then] to have a body is to learn to be affected, meaning 'effectuated', moved, put into motion by other entities, humans or nonhumans. If you are not engaged in this learning, you become insensitive, dumb, you drop dead" (qtd. in Pavlov-West 2013, 157). The narrator of Hyperdream is certainly aware of this ceaseless connection between organic and inorganic, human and non-human. When the narrator muses that "my book I say is on the move, we are moving each other" (Cixous 2006, 78), she hints to the fact that the book has just as much power over her as she has over the book; her book is an encounter of various texxtures.

Affective, tactile poetics in Hyperdream, then, is not contained in an individual but "refers to the fluid movement of feeling between surfaces as different texxtures" that make contact with one another (Jackson 2012, 414). The encounter between different texxtures becomes affective precisely when the subjects who experience these encounters are not coherent but fractured. Cixousian poetics, and her écriture féminine, is a move away from a coherent subject towards a more Deleuzian, complex, and fluid representation of subjectivity, where the latter is largely made up of affective contact with human and non-human worlds. The narrator of Hyperdream touches and affects, and is touched and affected by the book, and objects in the book, such as Benjamin's bed, the nightdress, and her mother's skin-her subjectivity, her self is an assemblage of all the things, ideas, and people she comes into contact with and that form a life. Accordingly, Cixousian model of the self cannot be understood solely in terms of psychoanalytical or deconstructionist readings but should be explored in the light of new materialist and affect theories because materiality and embodiment are pivotal in her writing per se, and her writing about selfhood. This affective writing assumes following a life; of going along new avenues that canonical philosophical and theoretical writings often avoid-paths that descend towards the earth to explore the texxture of the material world, rather than ascend in reach of transcendental heights. 


\section{Endnotes}

1. My aim here is not to offer a comprehensive overview or examination of Deleuze's and Guattari's various terms but to point out how Cixous's writing can be understood by certain concepts from Deleuze's and Guattari's writings such as 'a life,' 'multiplicity', and 'affect'. The most influential of their writings for this essay have been "Becoming-intense, becoming-animal" section of $A$ Thousand Plateaus, an essay 'Immanence: A Life,' and the section on art in What is Philosophy?'

2. My reference to Plato's cave in this essay functions first and foremost as a way of indicating that Cixous theorises and also practices a writing that is influenced by new materialist thinking, and Deleuzian philosophy-traditions that dissolve binaries and engage with what is inside the cave: material, embodied beings, human as well as non-human. In other words, I read her work with theories that do not aim to transcend the cave. Cixous writes about things close to earth that are unique in themselves, and she writes about them because they are important parts of ourselves and our lives.

3. Haecceity is a specific nuance about, or in relation to, a person or an object that makes it what it is, and is created in an encounter between movements and speeds. In $A$ Thousand Plateaus Deleuze and Guattari write: "There is a mode of individuation very different from that of a person, subject, things, or substance. We reserve the name haecceity for it. A season, a winter, a summer, an hour, a date have a perfect individuality lacking nothing, even though this individuality is different from that of a thing or a subject. They are haecceities in the sense that they consist entirely of relations of movement and rest between molecules or particles, capacities to affect and be affected" and "for you will yield nothing to haecceities unless you realise that this is what you are, and that you are nothing but that... you are longitude and latitude, a set of speeds and slownesses between unformed particles, a set of nonsubjectified affects. You have the individuality of a day, a season, a year, a life (regardless of its duration) - a climate, a wind, a fog, a swarm, a pack (regardless of its regularity)" (1980, 288-289).

4. To move beyond the phallocentric writing that focuses on the ego, the self, and identity, which Cixous also associates with both Freudian and Lacanian psychoanalysis, she urges writers in "The Laugh of Medusa" to "break out of the circles; don't remain within the psychoanalytic closure. Take a look around, then cut through!" (Cixous 1976, 892). In this sense, Cixousian writing also echoes 
Deleuze's and Guattari's criticism on psychoanalysis, and more specifically of Freudian concern with Oedipus complex in Anti-Oedipus: Capitalism and Schizophrenia (1972, p. 54).

5. See Toril Moi's Sexual/ Textual Politics (1985), Chris Weedon's Feminist Practice and Poststructuralist Theory (1987), and Joanna Zylinska's On Spiders, Cyborgs, and Being Scared (2001).

6. My understanding of feminist philosophy is influenced by the continental tradition but there are of course feminist philosophers in the analytical tradition who write from feminist perspective but focus on logical argumentation and the analysis of thoughts. For example, these philosophers include Daniel Stoljar, Sally Haslanger and Clare Chambers. My aim is not to undermine their work but to focus on the continental tradition.

\section{References}

Cixous, H. (1975). The Laugh of the Medusa. Translated by K. Cohen and P. Cohen. Signs, 1 (4), pp.875-893. Available at: https://edisciplinas.usp.br/ pluginfile.php/66416/mod_resource/content/1/cixous-the-laugh-of-themedusa.pdf. [Accessed 5 Nov. 2018].

Cixous, H. and Clément, C. (1975). Sorties: Out and Out: Attacks/Ways Out/ Forays. In The Newly Born Woman. Translated by B. Wing. Minneapolis: University of Minnesota Press.

Cixous, H. (1993). Three Steps on the Ladder of Writing. Translated by S. Cornell and S. Sellers. London: Columbia University Press.

Cixous, H. and Calle-Gruber, M. (1994). Rootprints: Memory and Life Writing. Translated by E. Prenowitz. London: Routledge.

Cixous, H. (2006). Hyperdream. Translated by B. B. Brahic. Cambridge: Polity.

Deleuze, G. and Guattari, F. (1991). What is Philosophy? Translated by H. Tomlinson and G. Burchell. New York: Columbia University Press.

—. (1980). A Thousand Plateaus. Translated by B. Massumi. New York: Continuum International Publishing Group. 
- (1972). Anti-Oedipus: Capitalism and Schizophrenia. Translated by R. Hurley, M. Seem, and H. R. Lane.

Deleuze, G. (1995). Pure Immanence: Essays on A Life. Translated by A. Boyman. London: The MIT Press.

Gregg, M. and G.J. Seigworth. (2010). The Affect Theory Reader. London: Duke University Press.

Grosz, E. (1990). Philosophy. In: S. Gunew ed., Feminist Knowledge: Critique and Construct. London: Routledge, pp.147-175.

Hanrahan, M. (2000). Of Altobiography. Paragraph: A Journal of Modern Critical Study, 23 (3), pp. 282-296. Available at: https://www.euppublishing.com/ doi/abs/10.3366/para.2000.23.3.282. [Accessed 5 Nov. 2018].

Irigaray, L. (1985). Speculum of the Other Woman. Translated by G. C. Gill. New York: Cornell University Press.

Jackson, S. (2012). So Close: Writing that Touches. New Writing: The International Journal for the Practice and Theory of Creative Writing, 9, (3), pp.408-418. Available at: https://www.tandfonline.com/doi/full/10.1080/1 4790726.2012.693096. [Accessed 5 Nov. 2018].

Tampio, N. (2010). Multiplicity. In: M. Bevir ed., Encyclopedia of Political Theory. London: SAGE, pp. 911-912.

West-Pavlov, R. (2013). Temporalities. London: Routledge. 